\title{
PERANAN PROGRAM CSR PERBANKAN DALAM MENINGKATKAN \\ KESEJAHTERAAN MASYARAKAT \\ DI KABUPATEN KARAWANG
}

\author{
Dedi Sudrajat, Dian Hakip Nurdiansyah \\ Email: dianhakip110@gmail.com; dian.hakipnurdiansyah@staff.unsika.ac.id
}

\begin{abstract}
Tanggungjawab sosial perusahaan atau disebut Corporate Social Responsibility (CSR) merupakan strategi perusahaan dalam mengakomodasi kebutuhan dan kepentingan stakeholdernya. Pelaksanaan CSR membutuhkan dukungan pemerintah daerah, kepastian hukum, dan jaminan ketertiban sosial. Salah satu dampak dari pendirian perusahaan oleh pemilik modal yang tergabung dalam sebuah corporation adalah muncul kesenjangan antara pihak perusahaan (corporate) dengan masyarakat setempat yang dapat mempengaruhi kestabilan negara. Suatu perusahaan sebagai organisasi sosial perlu berinteraksi dengan lingkungan sosialnya. Oleh karena itu instansi perlu memberikan perhatian kepada lingkungannya terhadap dampak yang ditimbulkan dari kegiatan operasional instansi dengan menjalankan program CSR. Perbankan dalam hal ini memiliki banyak hubungan secara langsung dengan masyarakat dalam bidang peningkatan ekonomi. Oleh karena itu sebagai bentuk tanggungjawab sosial kepada masyarakat, beberapa perbankan menyalurkan program program bina lingkungan tersebut terdiri atas pembangunan sarana umum, bantuan bencana alam, sarana pendidikan, kesehatan dan ibadah, serta pelestarian lingkungan.
\end{abstract}

Keyword : Corporate Social Responsibility (CSR)

\section{PENDAHULUAN}

Tanggungjawab sosial perusahaan atau disebut Corporate Social Responsibility (CSR) merupakan strategi perusahaan dalam mengakomodasi kebutuhan dan kepentingan stakeholder-nya. CSR timbul sejak era dimana kesadaran akan sustainability perusahaan jangka panjang adalah lebih penting daripada sekedar profitability. Sebagai bentuk tanggungjawab mereka terhadap sosial/lingkungan sekitar dimana perusahaan itu berada. Dimana bentuk tanggungjawab itu bermacammacam, mulai dari melakukan kegiatan yang dapat meningkatkan kesejahteraan masyarakat dan perbaikan lingkungan, pemberian beasiswa untuk anak tidak mampu, pemberian dana untuk pemeliharaan fasilitas umum, sumbangan untuk desa/fasilitas masyarakat yang bersifat sosial dan berguna untuk masyarakat banyak, khususnya masyarakat yang berada di sekitar perusahaan tersebut berada.

Pelaksanaan CSR membutuhkan dukungan pemerintah daerah, kepastian hukum, dan jaminan ketertiban sosial. Pemerintah dapat mengambil peran penting tanpa harus melakukan regulasi di tengah situasi hukum dan politik saat ini. Suatu perusahaan sebagai organisasi sosial perlu berinteraksi dengan lingkungan sosialnya. Oleh karena itu instansi perlu memberikan perhatian kepada lingkungannya terhadap dampak yang ditimbulkan dari kegiatan operasional instansi dengan menjalankan program CSR. Perbangkan dalam hal ini memiliki banyak hubungan secara langsung dengan masyarakat dalam bidang peningkatan ekonomi, oleh karena itu sebagai bentuk tanggungjawab sosial kepada 
masyarakat beberapa perbankan menyalurkan program program bina lingkungantersebut terdiri atas pembangunan sarana umum, bantuan bencana alam, sarana pendidikan, kesehatan dan ibadah, serta pelestarian lingkungan.

\section{TINJAUAN PUSTAKA}

\section{A. Pengertian CSR}

Tanggungjawab sosial perusahaan diartikan pula sebagai komitmen bisnis untuk berkontribusi dalam pembangunan ekonomi berkelanjutan, bekerja dengan para karyawan perusahaan, keluarga karyawan dan masyarakat setempat (lokal) dalam rangka meningkatkan kualitas kehidupan Corporate Social Responsibility dalam bahasa Indonesia dikenal dengan tanggungjawab sosial perusahaan sedangkan di Amerika, konsep ini seringkali disamakan dengan corporate citizenship. Pada intinya, keduanya dimaksudkan sebagai upaya perusahaan untuk meningkatkan kepedulian terhadap masalah sosial dan lingkungan dalam kegiatan usaha dan juga pada cara perusahaan berinteraksi dengan stakeholder yang dilakukan secara sukarela.

Dalam hal ini belum ada definisi tunggal mengenai pengertian dari CSR. Berikut ini adalah definisi-definisi dari CSR yang antara lain: The World Business Council for sustainable Development (WBCSD), lembaga internasional yang berdiri tahun 1995 dan beranggotakan lebih dari 120 perusahaan multinasional yang berasal dari 30 negara memberikan definisi CSR sebagai "continuing commitment by business to behave ethically and contribute to economic development while improving the quality of life of the workforce and their families as well as of the local community and society at large". Dalam hal ini, apabila diterjemahkan secara bebas kurang lebih berarti komitmen dunia usaha untuk terus-menerus bertindak secara etis, beroperasi secara legal dan berkontribusi untuk peningkatan ekonomi, bersamaan dengan peningkatan kualitas hidup dari karyawan.

Apabila diterjemahkan secara bebas, CSR berarti keterbukaan dan transparan dalam pelaksanaan usahanya yang dilandasi oleh nilai-nilai etika dan penghargaan kepada karyawan-karyawan, masyarakat setempat, dan lingkungan hidup. Sementara itu sejumlah negara juga mempunyai definisi tersendiri mengenai CSR. Uni Eropa (EU Green Paper on CSR) mengemukakan bahwa "CSR is a concept whereby companies integrate social and environmental concerns in their business operations and in their interaction with their stakeholders on a voluntary basic".

Undang-Undang Perseroan Terbatas juga mengatur ketentuan mengenai CSR. Pengertian CSR diatur di dalam Pasal 1 butir (3) UUPT, dalam hal ini CSR disebut sebagai tanggung jawab sosial dan lingkungan (TJSL) yang berarti komitmen Perseroan untuk berperan serta dalam pembangunan ekonomi berkelanjutan guna meningkatkan kualitas kehidupan dan lingkungan yang bermanfaat, baik bagi Perseroan sendiri, komunitas setempat, maupun masyarakat pada umumnya. Mengenai pelaksanaan CSR ini harus dimuat di dalam laporan tahunan perseroan yang disampaikan oleh direksi daft ditelaah oleh dewan komisaris yang mengharuskan memuat laporan pelaksanaan tangung jawab sosial dan lingkungan (Pasal 66 ayat (2) huruf c UUPT). Dalam hal ini, UUPT mewajibkan bagi setiap perseroan yang menjalankan kegiatan usaha di bidang dan/ atau berkaitan dengansumber daya alam untuk melaksanakan tanggung jawab sosial dan lingkungan. Hal 
ini ditegaskan. dalam Pasal 74 ayat (1) UUPT yang menyatakan bahwa perseroan yang menjalankan kegiatan usahanya di bidang dan/ atau berkaitan dengan sumber daya alam wajib melaksanakan tanggung jawab sosial dan lingkungan. Tanggungjawab sosial perusahaan terkait dengan nilai dan standar yang dilakukan berkenaan dengan beroperasinya sebuah perusahaan (corporate), maka CSR didefinisikan sebagai komitmen usaha untuk bertindak secara etis, beroperasi secara legal, dan berkontribusi untuk meningkatkan kualitas hidup dari karyawan dan keluarganya, komunitas lokal dan masyarakat secara lebih luas (Sankat, Clement K 2002). Dalam berbagai wacana Corporate Social Responsibility dapat diartikan secara luas dan universal seperti berikut:

\section{World Business Council for Sustainable Development}

Komitmen berkesinambungan dari kalangan bisnis untuk berperilaku etis dan memberi kontribusi bagi pembangunan ekonomi, seraya meningkatkan kualitas kehidupan karyawan dan keluargnya, serta komunitas lokal dan masyarakat luas pada umumnya.

2. International Finance Corporation

Komitmen dunia bisnis untuk memberi kontribusi terhadap pembangunan ekonomi berkelanjutan melalui kerjasama dengan karyawan, keluarga mereka, komunitas lokal dan masyarakat luas untuk meningkatkan kehidupan mereka melalui cara-cara yang baik bagi bisnis maupun pembangunan.

\section{Institute of Chartered Accountants, England and Wales}

Jaminan bahwa organisasi-organisasi pengelola bisnis mampu memberi dampak positif bagi masyarakat dan lingkungan, seraya memaksimalkan nilai bagi para pemegang saham (shareholders) mereka.

\section{European Commission}

Sebuah konsep dengan mana perusahaan mengintegrasikan perhatian terhadap sosial dan lingkungan dalam operasi bisnis mereka dan dalam interaksinya dengan para pemangku kepentingan (stakeholders) berdasarkan prinsip kesukarelaan.

5. CSR Asia

Komitmen perusahaan untuk beroperasi secara berkelanjutan berdasarkan prinsip ekonomi, sosial dan lingkungan, seraya menyeimbangkan beragam kepentingan para stakeholders.

\section{ISO 26000 mengenai Guidance on Social Responsibility}

Tanggung jawab sebuah organisasi terhadap dampak-dampak dari keputusankeputusan dan kegiatan-kegiatannya pada masyarakat dan lingkungan yang diwujudkan dalam bentuk perilaku transparan dan etis yang sejalan dengan pembangunan berkelanjutan dan kesejahteraan masyarakat; mempertimbangkan harapan pemangku kepentingan, sejalan dengan hukum yang ditetapkan dan norma-norma perilaku internasional; serta terintegrasi dengan organisasi secara menyeluruh (draft 3, 2007).

Tanggungjawab sosial merupakan Pasal yang tidak dapat dipisahkan dari good corporate governance karena pelaksanaan Corporate Social Responsibilitymerupakan Pasal dari salah satu prinsip yang berpengaruh dalam good corporate governance. Pada dasarnya ada lima prinsip dalam good corporate governance, yaitu Transparansi, Akuntabilitas, Responsibilitas, Independensi, dan Kesetaraan dan Kewajaran.

Prinsip yang berkaitan erat dengan CSR adalah Responsibilitas yang merupakan aspek pertanggungjawaban dari setiap kegiatan perusahaan untuk melaksanakan prinsip corporate social responsibility karena dalam berusaha, sebuah perusahaan tidak akan lepas dari masyarakat sekitar, ditekankan juga pada signifikasi filantrofik yang diberikan dunia usaha kepada kepentingan pihak-pihak eksternal dimana perusahaan diharuskan 
memperhatikan kepentingan stakeholder perusahaan, menciptakan nilai tambah (value added) dari produk dan jasa, dan memelihara kesinambungan nilai tambah yang diciptakannya.Diluar itu, lewat prinsip responsibility diharapkan membantu pemerintah dalam mengurangi kesenjangan pendapatan dan kesempatan kerja pada segmen masyarakat yang belum mendapatkan manfaat dari mekanisme pasar. Corporate Social Responsibility sebagai sebuah gagasan, perusahaan tidak lagi dihadapkan pada tanggungjawab yang berpijak pada single bottom line yaitu nilai perusahaan (corporate value) yang direfleksikan dalam kondisi keuangannya (financial saja) tetapi harus berpijak pada triple bottom lines, dimana bottom lines selain financialjuga adalah sosial dan lingkungan. Karena kondisi keuangan saja tak cukup menjamin nilai perusahaan tumbuh secara berkelanjutan (sustainable).Berdasarkan standar dari Bank Dunia maka CSR meliputi beberapa komponen utama yakni (1) perlindungan lingkungan (2) jaminan kerja (3) Hak Asasi Manusia (4) interaksi dan keterlibatan perusahaan dengan masyarakat (5) standar usaha (6) pasar (7) pengembangan ekonomi dan badan usaha (8) perlindungan kesehatan (9) kepemimpinan dan pendidikan (10) bantuan bencana kemanusiaan. Bagi perusahaan yang berupaya untuk membangun citra positif perusahaannya, maka kesepuluh komponen tersebut harus diupayakan pemenuhannya.

Dampak dari pendirian perusahaan oleh pemilik modal yang tergabung dalam sebuah corporation salah satunya adalah muncul kesenjangan antara pihak perusahaan (corporate) dengan masyarakat setempat yang dapat mempengaruhi kestabilan negara, disisi lain pemerintah terkadang tidak bisa berbuat banyak dalam memenui semua tuntutan masyarakat yang merasa hak-hak atas daerahnya dilanggar termasuk hak asasi seperti terusiknya tempat tinggal dan berkurangnya mata pencarian anggota masyarakat disekitar perusahaan. Dalam meminimalisir akibat tersebut, peran dari program corporate social responsibility sangat besar.

Lebih dari itu ketika pembangunan perusahaan telah sesuai dengan kawasan peruntukannya, maka pengusaha perlu melaksanakan berbagai kewajiban untuk meminimalisir kerugian yang dialami konsumen, karyawan, investor, maupun kerusakan kualitas lingkungan hidup antara lain :

a. Kewajiban terhadap konsumen

$\checkmark$ Konsumen memiliki hak untuk mendapatkan produk yang aman.

$\checkmark$ Konsumen memiliki hak untuk mendapatkan informasi tentang spesifikasi produk yang dijual perusahaan, antara lain dengan mencantumkan label yang benar.

$\checkmark$ Konsumen memiliki hak untuk didengarkan, perusahaan dapat membuka kontak pelanggan melalui kotak pos atau nomor telepon.

$\checkmark$ Konsumen memiliki hak untuk dapat dapat memilih barang yang mereka beli.

$\checkmark$ Kolusi dalam penetapan harga yang merugikan konsumen tidak dilakukan.

$\checkmark$ Kampanye iklan tidak dilakukan secara berlebihan.

b. Kewajiban terhadap karyawan

$\checkmark$ Melakukan proses seleksi dan penempatan pegawai secara transparan dengan mengajak para calon pegawai dari sekitar komunitas untuk berpartisipasi.

$\checkmark$ Memberikan posisi jabatan dan balas jasa gaji dan pengupahan, serta promosi jabatan tanpa memandang agama, gender, suku bangsa, senioritas dan asal negara.

$\checkmark$ Mematuhi peraturan dan UU ketenagakerjaan yang dikeluarkan oleh Pemerintah.

c. Kewajiban terhadap investor

$\checkmark$ Meniadakan berbagai potensi kecurangan yang mungkin timbul di perusahaan terhadap investor.

$\checkmark$ Menghindari praktek pembuatan laporan keuangan yang disemir dan tidak sesuai

Manajerial, Vol. 2 No. 2 Januari 2017, Hal - 16

http://ejournal.upi.edu/index.php/manajerial/

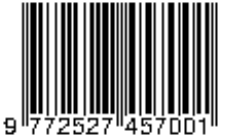


dengan standar pelaporan akuntansi yang berlaku.

$\checkmark$ Tidak melakukan perbuatan ilegal seperti mengeluarkan cek kosong dan proses pencucian uang (money laundry).

$\checkmark$ Tidak melakukan proses "insider trading" dalam menjual surat berharga perusahaan.

$\checkmark$ Mematuhi ketentuan tentang GAAP (Generally Accepted Accounting Practices), ketentuan pasar modal bagi para emiten dan pedoman GCG yang diberlakukan perusahaan.

d. Kewajiban terhadap Masyarakat dan Lingkungan Hidup

$\checkmark$ Menjalankan program community social responsibility, khususnya yang berkaitan dengan pelestarian kualitas lingkungan hidup.

$\checkmark$ Memperhitungkan dampak lintas sektor dalam proses produksi dengan memanfaatkan bahan baku alam secara berkelanjutan.

$\checkmark$ Menerapkan prinsip SIDEC, Sustainabilitas, Interdependence, Diversitas, Equity, Cohesion dalam pengelolaan dan pemanfaatan lingkungan alam

\section{B. JENIS CSR}

Terdapat 6 (enam) kategori aktivitas CSR (Kotler and Lee, 2005), yaitu :

\section{Cause Promotions}

Cause Promotions adalah aktivitas CSR yang dilakukan perusahaan dengan menyediakan dana atau sumber daya lainnya yangdimiliki perusahaan untuk meningkatkan kesadaran masyarakat terhadap suatu kegiatan sosial, atau untuk mendukung pengumpulan dana, partisipasi dari masyarakat atau perekrutan tenaga sukarela untuk suatukegiatan tertentu. Contoh kasus cause promotion ini dapat dilihat pada Perusahaan DELL yang mensponsori pengumpulan komputer bekas untuk di donasikan kepada organisasi non-profit dan organisasi publik.

\section{Cause-Related Marketing}

Aktivitas CSR cause-related marketing adalah perusahaan memiliki komitmen untuk menyumbangkan persentase tertentu dari penghasilannya untuk suatu kegiatan sosial berdasarkan besarnyapenjualan produk. Contoh perusahaan yang melakukan CSR kategori iniadalah Danone melalui produk aqua, dimana setiap 1 lier aqua yang terjual perusahaan akan menyumbangkan 101 air bersih untuk daerah-daerahyang masih mengalami kesulitan dalam mendapatkan air bersih.

3. Corporate Social Marketing

Perusahaan mengembangkan dan melaksanakan kampanye untuk mengubah perilaku masyarakat dengan tujuan meningkatkan kesehatan dan keselamatan publik, menjaga kelestarian lingkungan hidup, serta meningkatkan kesejahteraan masyarakat. Contoh perusahaan yang melakukan CSR ini adalah PT Unilever melalui produk lifebuoy dengan program 'Lifebuoy Berbagi Sehat'. Program ini mengkampanyekan hidup sehat salah satunya dengan mencuci tangan dengan menggunakan sabun. Perusahaan membagikan produk dan sosialisasi ke sekolah-sekolah untuk mensuskseskan program CSR ini.

4. Corporate Phylanthropy

Hal ini yang dilakukan oleh PERBANKAN dalam penerapan CSR perusahaan. Perusahaan memberikan sumbangan langsung dalam bentuk derma untuk kalangan masyarakat tertentu. Bantuan untuk kesehatan masyarakat meliputi biaya pengobatan, perawatan hingga penyembuhan melalui PPKI dan mendirikan fasilitas umum, serta 
menyediakan alat-alat berat untuk membantu evakuasi saat terjadi bencana alam melalui Program Kita Peduli.

\section{Community Volunteering}

Perusahaan mendukung dan mendorong para karyawan, rekan pedagang eceran, atau para pemegang franchise agar menyisihkan waktunya secara sukarela guna membantu organisasi-organisasi masyarakat lokal maupun masyarakat yang jadi sasaran program.

Standard Chartered Bank melakukan CSR kategori ini sebagai wujud TJS perusahaan. Setiap karyawan akan diberi reward berupa cuti kerja untuk waktu yang digunakan dalam setiap kegiatan CSR perusahaan.

6. Social Responsible Business Practice

Perusahaan melaksanakan aktivitas bisnis melampaui aktivitas bisnis yang diwajibkan oleh hukum dan melaksanakan investasi yang mendukung kegiatan sosial dengan tujuan meningkatkan kesejahteraan komunitas, serta memelihara lingkungan hidup. McDonald menggunakan material berbahan daur ulang pada pengemasannya sebagai wujud CSR perusahaan sebagai contoh CSR kategori ini. Menurut Suharto dalam Kusumadilaga (2010) yang berkaitan dengan pelaksanaan CSR, perusahaan dapat dikelompokkan ke dalam beberapa kategori.

Meskipun cenderung menyederhanakan realitas, tipologi ini menggambarkan kemampuan dan komitmen perusahaan dalam menjalankan CSR. Pengelompokkan ini dapat memotivasi perusahaan dalam mengembangkan program CSR dan dapat pula dijadikan cermin, serta panduan untuk menentukan model CSR yang tepat. Dengan menggunakan dua pendekatan, sedikitnya ada delapan kategori perusahaan. Pendekatan pertama berdasarkan proporsi Keuntungan perusahaan dan besarnya anggaran CSR. Dalam hal ini, terdapat 4 (empat) kategori perusahaan dalam pendekatan ini :

Berdasarkan proporsi keuntungan perusahaan dan besarnya anggaran CSR, perusahaan terdiri atas 4 (empat) kategori berikut (Suharto dalam Kusumadilaga, 2010) :

1. Perusahaan Minimalis, yaitu perusahaan yang memiliki profit dan anggaran CSR yang rendah. Perusahaan kecil dan lemah biasanya termasuk kategori ini.

2. Perusahaan Ekonomis adalah perusahaan yang memiliki keuntungan tinggi, namun anggaran CSR rendah. Perusahaan yang termasuk kategori ini adalah perusahaan besar, namun pelit.

3. Perusahaan Humanis merupakan perusahaan yang meskipun profit rendah,proporsi anggaran CSR relatif tinggi. Perusahaan pada kategori ini disebut perusahaan dermawan atau baik hati.

4. Perusahaan Reformis adalah perusahaan ini memiliki profit dan anggaranCSR tinggi. Perusahaan seperti ini memandang CSR bukan sebagai beban, melainkan sebagai peluang untuk lebih maju.

Pendekatan kedua adalah berdasarkan tujuan CSR yang dilakukanperusahaan, apakah untuk promosi atau pemberdayaan masyarakat. Terdapat 4 (empat) kategori perusahaan yaitu :

1. Perusahaan Pasif, dimana perusahaan yang menerapkan CSR tanpa tujuan jelas, yaitu bukan untuk promosi, bukan pula untuk pemberdayaan, tetapisekadar melakukan kegiatan kreatif perusahaan sebagai bentuk promosidan hal yang kurang bermanfaat bagi perusahaan.

2. Perusahaan Impresif, dimana perusahaan lebih mengutamakan CSR untukpromosi daripada untuk pemberdayaan masyarakat. Perusahaan seperti inilebih mementingkan tebar pesona daripada tebar karya. 
3. Perusahaan Agresif merupakan perusahaan yang kegiatan CSR lebih ditujukan untuk pemberdayaan daripada promosi. Perusahaan seperti inilebih mementingkan karya nyata daripada tebar pesona.

4. Perusahaan Progresif adalah perusahaan yang menerapkan CSR untuktujuan promosi dan sekaligus pemberdayaan. Promosi dan CSR dipandangsebagai kegiatan yang bermanfaat dan menunjang satu-sama lain bagi kemajuan perusahaan

Menurut Poerwanto (2010), secara konseptual terdapat 3 (tiga) pendekatan dalam pembentukkan CSR, yaitu :

1. Pendekatan moral, yaitu kebijakan atau tindakan yang didasarkan pada prinsip kesantunan dan nilai-nilai positif yang berlaku, dengan pengertianbahwa apa yang dilakukan tidak melanggar atau merugikan pihak-pihaklain.

2. Pendekatan kepentingan bersama, yaitu menyatakan bahwa kebijakankebijakanmoral harus didasarkan padastandar kebersamaan, kewajaran, keterbukaan dan kebebasan.

3. Pendekatan manfaat adalah konsep TJS yang didasarkan pada nilai-nilai bahan apa yang dilakukan oleh organisasi harus dapat menghasilkan manfaat besar bagi pihak-pihak berkepentingan secara adil. Berdasarkan pendekatan tersebut, CSR tidak dapat disebut sebagai beban perusahaan karena CSR merupakan bentuk moral atau etika perusahaan yang menjadi kepentingan bersama berbagai pihak terkait yang akan menunjang keberlangsungan usaha suatu perusahaan. Hal ini tentu saja akan membawa manfaat bagi perusahaan dalam jangka panjang, sehingga CSR dapat dikategorikan dalam tiga aktivitas yang dikenal dengan Triple Bottom Linesmeliputi 3P, yaitu profit, people dan planet. Profit berarti perusahaan memberikan manfaat keuntungan kepada shareholder, people diwujudkan dalam bentuk kepedulian terhadap stakeholder dan masyarakat sekitar, serta planet merupakan bentuk aktivitas CSR perusahaan sebagai wujud kepedulian terhadap lingkungan.

\section{Pengertian Kesejahteraan}

Menurut Undang-undang No 11 Tahun 2009, Kesejahteraan Sosial adalah kondisi terpenuhinya kebutuhan material, spiritual, dan sosial warga negara agar dapat hidup layak dan mampu mengembangkan diri, sehingga dapat melaksanakan fungsi sosialnya. Permasalahan kesejahteraan sosial yang berkembang dewasa ini menunjukkan bahwa ada warga negara yang belum terpenuhi hak atas kebutuhan dasarnya secara layak karena belum memperoleh pelayanan sosial dari negara. Akibatnya, masih ada warga negara yang mengalami hambatan pelaksanaan fungsi sosial sehingga tidak dapat menjalani kehidupan secara layak dan bermartabat.

Konsep kesejahteraan menurut Nasikun (1993) dapat dirumuskan sebagai padanan makna dari konsep martabat manusia yang dapat dilihat dari empaat indicator yaitu : (1) rasa aman (security), (2) Kesejahteraan (welfare), (3) Kebebasan (freedom), dan (4) jati diri (Identity). Biro Pusat Statistik Indonesia (2000) menerangkan bahwa guna melihat tingkat kesejahteraan rumah tangga suatu wilayah ada beberapa indicator yang dapat dijadikan ukuruan, antara lain adalah :

1. Tingkat pendapatan keluarga;

2. Komposisi pengeluaran rumah tangga dengan membandingkan pengeluaran untuk pangan dengan non-pangan;

3. Tingkat pendidikan keluarga; 
4. Tingkat kesehatan keluarga, dan; Kondisi perumahan serta fasilitas yang dimiliki dalam rumah tangga.

Namun, kita harus hati-hati dalam menggunakan pendapatan per kapita sebagai suatu indikator pembangunan. Sebab ada pendapat yang mengatakan pembangunan bukan hanya sekedar meningkatkan pendapatan riil saja, tetapi kenaikan tersebut harus berkesinambungan dan mantap serta harus disertai pula dengan perubahan-perubahan sikap dan kebiasaan-kebiasaan sosial yang sebelumnya menghambat kemajuan-kemajuan ekonomi.

\section{METODOLOGI PENELITIAN}

Metode penelitian pada dasarnya merupakan cara alamiah untuk mendapatkan data dengan tujuan dan kegunaan tertentu. setiap penelitian mempunyai tujuan dan kegunaan tertentu. secara umum tujuan penelitian ada tiga macam yaitu yang bersifat penemuan, pembuktian, dan pengembangan. Melalui penelitian manusia dapat menggunakan hasilnya. Secara umum data yang diperoleh dari penelitian dapat digunakan untuk memahami, memecahkan dan mengantisipasi masalah. Memahami berarti memperjelas suatu masalah atau informasi yang tidak diketahui dan selanjutnyas menjadi tahu. Memecahkan berarti meminimalkan atau menghilangkan masalah. Sedangkan mengantisipasi adalah mengupayakan agar masalah tidak terjadi.

\section{A. Jenis penelitian}

\section{Penelitian dipandang dari cara pembahasannya}

Dalam penelitian kali ini jika dipandang dari cara pembahasannya termasuk kedalam penelitian deskriptif. Dimana penelitian ini melukiskan, memaparkan, menuliskan dan melaporkan suatu keadaan suatu objek peristiwa fakta apa adanya.

\section{Penelitian ditinjau dari segi tujuan}

Jika ditinjau dari segi tujuannya jenis penelitian ini merupakan penelitian terapan. Gay (1977) menyatakan bahwa penelitian terapan dilakukan dengan tujuan menerapkan, menguji, dan mengevaluasi kemampuan suatu teori yang diterapkan dalam memecahkan masalah-masalah praktis dan penelitian ini berkenaan dengan penggunaan prinsip-prinsip.

\section{Penelitian ditinjau dari metode}

Ditinjau dari metode penelitian yang akan digunakan dalam penelitian ini adalah metode korelasi. Metode korelasi adalah suatu metode dalam penelitian yang menyelidiki hubungan antar dua buah variabel atau lebih terdiri dari variabel terikat dan variabel bebas. Dalam penelitian kali ini metode korelasi akan memberikan gambaran tentang hubungan antara dua variabel bebas dan terikat. Variabel yang sederhana menurut Sudjana (1992 : 3) dapat diartikan " ciri dari individu, objek, gejala, peristiwa, yang dapat diukur secara kuantitatif ". Pendapat tersebut didukung oleh Arikunto (1996:91) yang mengemukakan bahwa "variabel adalah objek penelitian atau apa yang menjadi titik perhatian". Dalam penelitian kali ini penulis berdasarkan pada pendapat Arikunto yang menjelaskan bahwa " ada variabel yang mempengaruhi dan ada variabel akibat'. Variabel yang mempengaruhi disebut variabel bebas atau independent variabel yaitu faktor (hal 
sedangkan variabel akibat disebut variabel terikat atau dependent variabel yaitu gejala yang muncul atau berubah yang biasa diamati atau karena berubahnya variabel lain.

Berdasarkan hal tersebut diatas, maka variabel dalam penelitian ini terdiri dari variabel bebas (X) dan variabel terikat (Y). Dimana variabel bebas (X) dalam penelitian ini adalah Program CSR Perbankandan variabel terikat (Y) dalam penilitian ini adalah Kesejahteraan Masyarakat di Kabupaten Karawang.

\section{B. Waktu dan Tempat Penelitian}

Waktu untuk pembuatan skripsi ini sekitar kurang lebih 3(tiga) bulan dimulai pada bulan Nopember dan berakhir pada bulan Januari 2012. Lokasi penelitian yang penulis lakukan adalah di Kabupaten Karawang dan lembaga perbankan khususnya di Bank BRI Karawang.

\section{Populasi dan Sample Penelitian}

Dalam menentukan populasi, sampel dan teknik sampling ada beberapa hal yang harus diperhatikan. Pertama, tentukan siapa atau apa dan di mana populasi atau sekumpulan orang atau barang (benda) yang akan dijadikan subjek penelitian oleh kita. Kedua, pertimbangkan populasi itu dengan kebutuhan penelitian dari segi kuantitasnya. Ketiga, pertimbangkan kemampuan, baik dari segi waktu, biaya/dana, dan pengetahuan kita. Keempat, pertimbangkan segi homogen dan heterogennya populasi itu untuk menentukan cara pengambilan sampel.

\section{Populasi}

Populasi merupakan sekumpulan sebaran objek suatu tempat yang mempunyai karakteristik tertentu yang diterapkan oleh peneliti untuk dipelajari dan kemudian ditarik kesimpulannya untuk keperluan penelitian untuk dipelajari dan kemudian seluruh anggota populasi dapat dijadikan subjek penelitian jika jumlah anggota relative sedikit, sehingga tidak memungkinkan untuk penarikan sampel. Sebaliknya jika anggota populasi berjumlah sangat besar maka perlu dilakukan penarikan sampel atas populasi. Kaliamt di atas diperkuat lagi menurut Sugiono (1994:57) “ wilayah generalisasi yang terdiri atas objek atau subjek yang mempunyai kuantitas dan karakteristik tertentu yang ditetapkan oleh peneliti untuk dipelajari dan kemudian ditarik kesimpulannya".Menurut Arikunto (2006) populasi adalah sekelompok objek yang akan diselidiki. Arikunto mengatakan bahwa apabila populasinya kurang dari 100 maka sebaiknya diambil 10 sampel.

\section{Sample}

Menurut Sugiarto (2003:90) "sampel adalah bagian dari jumlah karakteristik yang dimiliki oleh populasi tersebut". Sementara Arikunto (2006 : 131) menyatakan bahwa "sampel adalah sebagian atau wakil dari populasi yang diteliti". Sugiyono (2011:86) mengemukakan makin besar jumlah sampel mendekati populasi, maka peluang kesalahan generalisasi semakin kecil dan sebaliknya makin kecil jumlah sampel menjauhi populasi, maka makin besar kesalahan generalisasi. Pada penelitian ini, teknik yang digunakan yaitu purposive random sampling, yaitu teknik pengambilan sampling secara acak yang ditentukan oleh peneliti disesuaikan dengan tujuan peneliti sehingga persyaratan sampling harus sesuai dengan kondisi yang diinginkan oleh peneliti.

\section{Objek Penelitian}

Adapun yang menjadi objek penelitian yang dilakukan oleh peneliti adalah mereka yang menjadi penerima CSR Baik Perorangan maupun lembaga serta perangkat di 
Perbankan yang ada di kabupatenkarawang.

\section{Operasionalisasi Variabel}

Menurut Nasir (1998:152) "Operasionalisasi variabel adalah definisi yang diberikan kepada suatu variabel dengan cara memberikan arti atau mengekspresikan kegiatan atau memberikan suatu operasional yang diperlukan untuk mengukur variable tersebut".

Tabel 3.1

Operasionalisasi Variabel

\begin{tabular}{|c|c|c|c|}
\hline No & Variabel & Dimensi Variabel & $\begin{array}{c}\text { Indikator Dimensi } \\
\text { Variabel }\end{array}$ \\
\hline 1. & $\begin{array}{l}\text { Variabel Bebas } \\
\text { Program } \\
\text { Perbankan }(\mathrm{X})\end{array}$ & $\begin{array}{l}\text { Program Bina } \\
\text { Lingkungan }\end{array}$ & $\begin{array}{l}\text { Jenis Perusahaan } \\
\text { Jumlah Asset } \\
\text { Jumlah Karyawan } \\
\text { Lama Perusahaan } \\
\text { Jenis Program } \\
\text { Banyaknya CSR } \\
\text { Jenis Bantuan CSR }\end{array}$ \\
\hline 2. & $\begin{array}{l}\text { Variabel Terikat } \\
\text { Kesejahteraan } \\
\text { Masyarakat } \\
\text { Karawang } \\
\text { (Y) }\end{array}$ & $\begin{array}{l}\text { Peningkatan } \\
\text { Kesejahteraan }\end{array}$ & $\begin{array}{c}\text { Jumlah Penduduk } \\
\text { Kemampuan Daya Beli } \\
\text { Tingkat pendidikan } \\
\text { Peluang Usaha } \\
\text { Jenis Usaha yg dominan } \\
\text { Tingkat Status Sosial }\end{array}$ \\
\hline
\end{tabular}

Sumber : Diolah Tahun 2014

Instrumen penelitian adalah alat yang digunakan oelh peneliti untuk mengumpulkan data. Instrumen penelitian ini bertujuan untuk memudahkan dalam menyarinag data dari responden. Instrumen penelitian dalam risetnya menggunakan quesioner / angket.

\section{a. Quesioner / angket}

Quesioner adalah sejumlah pertanyaan tertulis yang digunakan untuk memperoleh informasi dari responden. Jenis quesioner yang akan dipakai dalam penelitian ini adalah quesioner tertutup dan terbuka. Quesioner tertutup dimana beberapa pertanyaan yang diajukan sudah disediakan jawabannya sehingga responden tinggal memilih dan quesioner terbuka adalah pertanyhaan yang diberikan kepada responden memberikan kesempatan untuk menjawab dengan kalimat sendiri tanpa dipengaruhi oleh alternatifalternatif jawaban.

Teknik ini dengan cara mengedarkan daftar pertanyaan yang harus di isi oleh responden yang akan dijadikan sampel.Untuk pertanyaan tertutup perhitungan skor menggunakan skala perbedaan 5,4,3,2,1 dimana angka 5 mempunyai nilai tertinggi dari masing-masing jawaban sedangkan untuk pertanyaan terbuka penulis mengolah data dari jawaban-jawaban responden. 


\section{E. Teknik Pengumpulan Data}

Data dapat disebut sebagai keterangan tentang sesuatu baik berbentuk angkaangka bilangan maupun bukan angka-angka. Data yang berbentuk angka-angka disebut data kuantitatif sedangkan data yang bukan berbentuk angka disebut data kualitatif. Jenis data yang dikumpulkan yaitu data primer dan data sekunder. Data primer adalah data yang diperoleh dari penyebaran angket dan interview dengan responden yang diteliti, sedangkan data sekunder adalah data-data yang diperoleh dari berbagai referensi yang ada hubungannya atau relevansi dengan penelitian yang penulis teliti seperti dari literatur, dokumen-dokumen penelitian yang sudah, teoriteori yang relevan serta dengan studi kepustakaan dan internet.

Adapun teknik pengumpulan datanya adalah dengan cara :

\section{Quesioner / angket wawancara}

Quesioner merupakan alat pengumpul data untuk memperoleh data yang diinginkan dengan komplek berupa rangkaian pertanyaan tertulis yang ditunjukan kepada responden. Hasil yang didapat berupa jawaban dari responden untuk mendukung kelancaran dari penelitian ini, wawancara adalah sebuah dialog yang dilakukan oleh penanya untuk memperoleh informasi dari responden yang diwawancara. Ditinjau dalam pelaksanaannya maka wawancara dapat dibedakan menjadi :

a. Interview bebas dimana penanya bebas menanyakan apa saja tetapi mengingat akan data yang akan dikumpulkan dalam pelaksanaannya pewawancara tidak membawa pedoman atau sesuatu yang akan dipertanyakan kepada responden.

b. Interview terpimpin yaitu interview yang dilakukan oleh penanya dengan membawa sederet pertanyaan lengkap dengan terperinci, interview terpimpin yaitu kombinasi antara interview bebas dan interview terpimpin dalam pelaksanaannya pewawancara membawa pedoman yang hanya merupakan garis besar tentang halhal yang ditanyakan. Berdasarkan penjelasan di atas, maka dalam penelitian ini menggunakan interview bebas terpimpin dimana penulis menanyakan kepada responden hanya berupa garis besarnya saja tapi tetap dengan suasana yang santai dan calm agar data yang diperoleh sesuai dengan yang diharapkan.

\section{Studi kepustakaan dan internet}

Studi kepustakaan merupakan kegiatan penelusuran dan penelaahan literatur yang pada akhirnya dipelajari dan dicatat beberapa teori yang bersangkutan dengan penelitian ini, sehingga diperoleh sumber data sekunder yang mendukung penelitian. Hasil yang didapat berupa literatur dan teori-teori dari beberapa ahli untuk menunjang penelitian ini.

\section{F. Teknik Analisa Data}

Tujuan utama penelitian adalah mencari jawaban atas pertanyaan pertanyaan penelitian dalam rangka mengungkapkan masalah agar hal ini tercapai penelitian perlu melakukan tahapan - tahapan berupa rumusan hipotesis. Pengumpulan data memperoleh data, memproses data, analisis data, dan interprestasi data. 


\section{Teknik Kualitatif}

Untuk menganalisa sebuah penelitian secara kualitatif maka dibutuhkan instrumen pendukung penelitian yang dapat dibuktikan validitas dan reabilitas datanya tersebut dengan menggunakan Uji Validitas dan Reabilitas data.

\section{Teknik Kuantitatif}

Di dalam pengolahan data penelitian ini peneliti melakukan manajemen data yaitu pengolahan data sebagai salah satu kegiatan dalam penelitian yang bertujan untuk mengolah data - data yang diperoleh dari lapangan agar bisa dibaca dan mudah dipahami berdasarkan identifikasi masalah yang ditindak lanjuti dengan upaya penemuan informasi yang dibutuhkan maka atas data yang telah terkumpul yang diperoleh melalui observasi. Wawancara dan penyebaran kuesioner maka proses manajemen data dalam penelitian ini adalah untuk membandingkan hasil perhitungan dengan angka kritis tabel korelasi nilai $\mathrm{r}$ untuk menentukan korelasi yang signifikan. Suatu kuesioner dapat dikatakan reliabel atau handal jika kuesioner dalam satu variabel memiliki jawaban konsisten atau stabil dari waktu ke waktu, dengan syarat nilai ujireabilitas dapat menunjukkan nilai alpha lebih besar dari 0,6 (Ghozali, 2001).

\section{a. Persiapan}

Dalam tahap ini peneliti melakukan persiapan antara lain:

1) Mengecek nama dan kelengkapan identitas responden.

2) Mengecek kelengkapan data, artinya memeriksa instrument pengumpulan data.

\section{b. Inventarisasi data}

Dalam tahap ini peneliti melakukan pemilihan dan penyusunan data secara sistematis. Karena data yang diperoleh peneliti dari lapangan berupa data mentah yang belum diolah. Untuk itu perlu diatur secara sistematis agar data mudah dipahami.

\section{c. Tabulasi data}

Tabulasi merupakan proses pengolahan data yang dilakukan dengan cara memasukan data kedalam tabel. Menurut Kamus Besar Bahasa Indonesia ( 1995 ) tabulasi adalah data dalam bentuk tabel atau daftar untuk memudahkan dalam pengamatan dan evaluasi. Hasil dari tabulasi menjadi gambaran tentang hasil penelitian, karena data-data yang diperoleh dari lapangan sudah tersusun dan terangkum didalam tabel-tabel yang mudah dipahami maknanya.

Sedangkan untuk mengetahui keeratan hubungan antara variabel bebas (x) dengan variabel terikat (y) maka peneliti memasukan rumus dari koefisien korelasi. Koefisien korelasi adalah suatu alat statistik yang digunakan untuk membandingkan hasil pengukuran dua variabel agar dapat menentukan tingkat hubungan antara variabel - variabel dalam penelitian ini.

Rumus untuk menghitung korelasi yang digunakan dalam penelitian ini adalah:

$r_{x y}=\frac{n \sum x y-\sum x \sum y}{\sqrt{n \sum x^{2}-\left(\sum x^{2}\right)\left(n \sum y^{2}-\left(\sum y\right)^{2}\right.}}$ 
$\begin{array}{ll}\text { Keterangan : } & \\ \mathrm{n} \quad=\text { jumlah sampel } & \mathrm{y}=\text { variabel terikat } \\ \mathrm{x} \quad=\text { variabel bebas } & \text { rxy }=\text { koefisien korelasi }\end{array}$

Dalam tahap ini data - data yang telah disajikan dalam bentuk tabel pada tahap tabulasi kemudian dimasukan kedalam rumus koefisien korelasi tersebut lalu dihitung maka akan didapatkan koefisien korelasinya. Koefisien korelasi tersebut ditunjukan dalam bilangan $>0 \leq 1$

Jika koefisien korelasi $0-0,20$ artinya terdapat hubungan atau korelasi yang sangat rendah.

Jika koefisien korelasi 0,21 - 0,40 artinya terdapat hubungan atau korelasi rendah Jika koefisien korelasi 0,41 - 0,60 artinya terdapat hubungan atau korelasi sedang Jika koefisien korelasi 0,61 - 0,80 artinya terdapat hubungan atau korelasi tinggi Jika koefisien korelasi 0,81 - 0,99 artinya terdapat hubungan atau korelasi sangat tinggi.

Setelah diketahui korelasinya maka tahap selanjutnya mengtahui kebermaknaan (signifikan) koefisien korelasi dengan menggunakan

$$
\text { th }=\frac{\mathrm{rxy} \sqrt{\mathrm{n}-2}}{\sqrt{1-(\mathrm{rxy})^{2}}}
$$

Dari hasil analisis data maka dapat disimpulkan apakah hipotesis yang diajukan dapat diterima atau ditolak. Formula diatas merupakan $t$ hitung yang hasilnya akan dibandingkan dengan $t$ tabel. Jika $t$ hitung < dari t tabel maka hipotesis dapat diterima kebenarannya sehingga menjadi sebuah hipotesa dengan kata lain terjadi hubungan antara dua variabel yang signifikan.

\section{RESULTS AND DISCUSSION}

\section{A. Deskripsi Objek Penelitian}

Sebagai studi riset pada kegiatan CSR Perbankan di ambil sampel objek pada kegiatan CSR PT Bank Rakyat Indonesia Tbk dalam merealisasikan dana bina lingkungan hingga Rp55 miliar selama kuartal pertama tahun ini. Program bina lingkungan tersebut terdiri atas pembangunan sarana umum, bantuan bencana alam, sarana pendidikan, kesehatan dan ibadah, serta pelestarian lingkungan. "Realisasi Bina Lingkungan di bidang pembangunan sarana umum sebesar Rp 3 miliar, bantuan bencana alam sebesar Rp 150 juta, bidang pendidikan Rp 20 miliar, bidang kesehatan Rp 26 miliar, pembangunan sarana ibadah Rp 28 miliar dan bidang pelestarian lingkungan sebesar Rp 3 miliar,"

Adapun salah satu program pelestarian lingkungan yang baru saja dilakukan perseroan adalah penyebaran $500 \mathrm{~kg}$ benih ikan nila di danau kawasan Bukit Indah Purwakarta, Cikampek, Jawa barat. Ikan nila memiliki karakteristik pemakan gulma sehingga dapat mengendalikan pertumbuhan bunga. Oleh sebab itu perseroan memilih ikan nila agar dapat menjaga keseimbangan ekosistem danau yang sering terganggu gulma air seperti eceng gondok. Ikan nila dipilih karena memiliki tingkat toleransi yang baik terhadap lingkungan ekstrim sehingga mudah berkembang biak. "Selain dapat digunakan sebagai pengendali gulma, ikan nila juga dapat dikonsumsi sehingga apabila dikemudian hari ikan nila sudah bisa berkembang dengan baik, maka dapat dimanfaatkan hasilnya oleh penduduk sekitar danau" terangnya.

PT. Bank Rakyat Indonesia (BRI) Tbk menyisihkan lima persen dari total laba bersih

Manajerial, Vol. 2 No. 2 Januari 2017, Hal - 25

http://ejournal.upi.edu/index.php/manajerial/

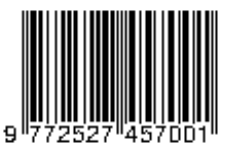


untuk dana bantuan hibah (corporate social responsibility/CSR). Dana bantuan hibah ini disalurkan untuk kegiatan produktif masyarakat. Jumlahnya selalu bertambah. Sehingga kalau masih tersisa, dana program CSR kita jadi bertambah. Sisa dana kita akumulatifkan untuk tahun berikutnya, BRI menargetkan penyaluran bantuan untuk para nelayan di Indonesia. Selama ini, lanjut dia, kondisi perekonomian nelayan di Indonesia cukup memprihatinkan. "Terlebih jika BBM jadi naik, dampaknya akan sangat dirasakan oleh para nelayan. Jika petani, meski BBM naik masih bisa berladang. Tapi kalau nelayan, jika tidak bisa beli BBM ya tidak bisa melaut,.

Hinga bulan Mei ini, Dedi mengatakan, jumlah dana CSR yang terkumpul sebanyak Rp 3 Triliun. Dana tersebut siap disalurkan dalam bentuk bantuan di segala bidang. Baik bidang sosial, agama, pendidikan, maupun olahraga. Selain itu, BRI turut memprioritaskan CSR sektor pendidikan berupa beasiswa."Jadi sebagian laba ini kami kembalikan lagi kepada rakyat dalam bentuk bantuan-bantuan sosial.

\section{B. Hasil Penelitian}

1. Deskripsi hasil penelitian terhadap variable CSR (Customer Social Responsibility) perbankan

Setelah melakukan tabulasi terhadap hasil questioner yang diteliti diketahui bahwa pada tabulasi frekuensi terhadap variable tentang CSR Dijelaskan pada table frequency sebagai berikut:

\begin{tabular}{|c|c|r|r|r|r|}
\hline \multirow{7}{*}{ Valid } & Frequency & Percent & \multicolumn{1}{|c|}{$\begin{array}{c}\text { Valid } \\
\text { percent }\end{array}$} & $\begin{array}{c}\text { Cumulative } \\
\text { percent }\end{array}$ \\
\cline { 2 - 6 } & Kurang baik & 1 & 3.0 & 3.0 & 3.0 \\
\cline { 2 - 6 } & Cukup baik & 11 & 33.3 & 33.3 & 36.4 \\
\cline { 2 - 6 } & $\begin{array}{l}\text { Baik/setuju/ } \\
\text { memuaskan }\end{array}$ & 12 & 36.4 & 36.4 & 72.7 \\
\cline { 2 - 6 } & Sangat baik & 9 & 27.3 & 27.3 & 100.0 \\
\cline { 2 - 6 } & Total & 33 & 100.0 & 100.0 & \\
\hline
\end{tabular}

\section{Banyaknya CSR}

\begin{tabular}{|c|c|r|r|r|r|}
\hline \multirow{7}{*}{ Valid } & \multicolumn{1}{|c|}{ Frequency } & Percent & \multicolumn{1}{|c|}{$\begin{array}{c}\text { Valid } \\
\text { percent }\end{array}$} & Cumulative percent \\
\cline { 2 - 6 } & Kurang baik & & & & 39.4 \\
\cline { 2 - 6 } & Cukup baik & 13 & 39.4 & 39.4 & 84.8 \\
\cline { 2 - 6 } & $\begin{array}{c}\text { Baik/setuju/ } \\
\text { memuaskan }\end{array}$ & 15 & 45.5 & 45.5 & 100.0 \\
\cline { 2 - 6 } & Sangat baik & 5 & 15.2 & 15.2 & \\
\cline { 2 - 6 } & Total & 33 & 100.0 & 100.0 & \\
\hline
\end{tabular}

\section{Jenis bantuan CSR}

\begin{tabular}{|c|c|c|c|c|c|}
\hline \multirow{3}{*}{ Valid } & & Frequency & Percent & $\begin{array}{l}\text { Valid } \\
\text { percent }\end{array}$ & $\begin{array}{c}\text { Cumulative } \\
\text { percent }\end{array}$ \\
\hline & Kurang baik & & & & \\
\hline & Cukup baik & 2 & 6.1 & 6.1 & 6.1 \\
\hline
\end{tabular}

Manajerial, Vol. 2 No. 2 Januari 2017, Hal - 26

http://ejournal.upi.edu/index.php/manajerial/ 


\begin{tabular}{|r|c|r|r|r|r|}
\hline \multirow{2}{*}{$\begin{array}{c}\text { Baik/setuju/ } \\
\text { memuaskan }\end{array}$} & 21 & 63.6 & 63.6 & 69.7 \\
\cline { 2 - 5 } & Sangat baik & 10 & 30.3 & 30.3 & 100.0 \\
\cline { 2 - 5 } & Total & 33 & 100.0 & 100.0 & \\
\hline
\end{tabular}

\section{Lembaga mitra penyalur}

\begin{tabular}{|c|c|r|r|r|r|}
\hline \multirow{7}{*}{} & Frequency & Percent & \multicolumn{1}{|c|}{$\begin{array}{c}\text { Valid } \\
\text { percent }\end{array}$} & \multicolumn{2}{c|}{$\begin{array}{c}\text { Cumulative } \\
\text { percent }\end{array}$} \\
\cline { 2 - 6 } & Kurang baik & 1 & 3.0 & 3.0 & 3.0 \\
\cline { 2 - 6 } & Cukup baik & 9 & 27.3 & 27.3 & 30.3 \\
\cline { 2 - 6 } & $\begin{array}{c}\text { Baik/setuju/ } \\
\text { memuaskan }\end{array}$ & 17 & 51.5 & 51.5 & 81.8 \\
\cline { 2 - 6 } & Sangat baik & 6 & 18.2 & 18.2 & 100.0 \\
\cline { 2 - 6 } & Total & 33 & 100.0 & 100.0 & \\
\hline
\end{tabular}

\section{Kriteria penerima}

\begin{tabular}{|c|c|r|r|r|r|}
\hline \multirow{7}{*}{ Valid } & \multicolumn{1}{|c|}{ Frequency } & Percent & \multicolumn{1}{c|}{$\begin{array}{c}\text { Valid } \\
\text { percent }\end{array}$} & \multicolumn{2}{c|}{$\begin{array}{c}\text { Cumulative } \\
\text { percent }\end{array}$} \\
\cline { 2 - 6 } & Kurang baik & 1 & 3.0 & 3.0 & 3.0 \\
\cline { 2 - 6 } & Cukup baik & 8 & 24.2 & 24.2 & 27.3 \\
\cline { 2 - 6 } & $\begin{array}{c}\text { Baik/setuju/ } \\
\text { memuaskan }\end{array}$ & 13 & 39.4 & 39.4 & 66.7 \\
\cline { 2 - 6 } & Sangat baik & 11 & 33.3 & 33.3 & 100.0 \\
\cline { 2 - 6 } & Total & 33 & 100.0 & 100.0 & \\
\hline
\end{tabular}

\section{Akuntabilitas kegiatan CSR}

\begin{tabular}{|c|c|r|r|r|r|}
\hline \multirow{7}{*}{ Valid } & \multicolumn{1}{|c|}{ Frequency } & \multicolumn{1}{c|}{ Percent } & \multicolumn{1}{c|}{$\begin{array}{c}\text { Valid } \\
\text { percent }\end{array}$} & \multicolumn{2}{c|}{$\begin{array}{c}\text { Cumulative } \\
\text { percent }\end{array}$} \\
\cline { 2 - 6 } & Kurang baik & 1 & 3.0 & 3.0 & 3.0 \\
\cline { 2 - 6 } & Cukup baik & 8 & 24.2 & 24.2 & 27.3 \\
\cline { 2 - 6 } & $\begin{array}{c}\text { Baik/setuju/ } \\
\text { memuaskan }\end{array}$ & 15 & 45.5 & 45.5 & 72.7 \\
\cline { 2 - 6 } & Sangat baik & 9 & 27.3 & 27.3 & 100.0 \\
\cline { 2 - 6 } & Total & 33 & 100.0 & 100.0 & \\
\hline
\end{tabular}

Dengan melakukan perhitungan jumlah total tabulasi pada nilai questioner sejumlah 1318 setelah di bandingkan dengan jumlah responden sebanyak 33 orang diketahui kegiatan CSR dengan nilai rata-rata skala likert sebesar 39,8 yang menunjukan nilai Baik.

\section{Deskripsi questioner variable Kesejahteraan Masyarakat}

Hasil questioner yang diteliti diketahui bahwa pada tabulasi frekuensi terhadap variable tentang Kesejahteraan dijelaskan sebagai berikut: 


\section{Frequency Table}

\section{Pendapatan Masyarakat}

\begin{tabular}{|c|c|r|r|r|r|}
\hline \multirow{7}{*}{ Valid } & \multicolumn{1}{|c|}{ Frequency } & \multicolumn{1}{c|}{ Percent } & \multicolumn{1}{c|}{$\begin{array}{c}\text { Valid } \\
\text { percent }\end{array}$} & $\begin{array}{c}\text { Cumulative } \\
\text { percent }\end{array}$ \\
\cline { 2 - 6 } & Kurang baik & 9 & 27.3 & 27.3 & 27.3 \\
\cline { 2 - 6 } & Cukup baik & 7 & 21.2 & 21.2 & 48.5 \\
\cline { 2 - 6 } & $\begin{array}{c}\text { Baik/setuju/ } \\
\text { memuaskan }\end{array}$ & 14 & 42.4 & 42.4 & 90.9 \\
\cline { 2 - 6 } & Sangat baik & 3 & 9.1 & 9.1 & 100.0 \\
\cline { 2 - 6 } & Total & 33 & 100.0 & 100.0 & \\
\hline
\end{tabular}

\section{Tingkat pendidikan}

\begin{tabular}{|c|c|r|r|r|r|}
\hline \multirow{7}{*}{ Valid } & Frequency & Percent & \multicolumn{1}{c|}{$\begin{array}{c}\text { Valid } \\
\text { percent }\end{array}$} & $\begin{array}{c}\text { Cumulative } \\
\text { percent }\end{array}$ \\
\cline { 2 - 6 } & Kurang baik & 9 & 27.3 & 27.3 & 27.3 \\
\cline { 2 - 6 } & Cukup baik & 16 & 48.5 & 48.5 & 75.8 \\
\cline { 2 - 6 } & $\begin{array}{l}\text { Baik/setuju/ } \\
\text { memuaskan }\end{array}$ & 8 & 24.2 & 24.2 & 100.0 \\
\cline { 2 - 6 } & Sangat baik & 33 & 100.0 & 100.0 & 27.3 \\
\cline { 2 - 6 } & Total & 9 & 27.3 & 27.3 & \\
\hline
\end{tabular}

\section{Daya beli masyarakat}

\begin{tabular}{|c|c|r|r|r|r|}
\hline \multirow{7}{*}{ Valid } & \multicolumn{1}{|c|}{ Frequency } & Percent & \multicolumn{1}{c|}{$\begin{array}{c}\text { Valid } \\
\text { percent }\end{array}$} & $\begin{array}{c}\text { Cumulative } \\
\text { percent }\end{array}$ \\
\cline { 2 - 6 } & Kurang baik & & & & 3.0 \\
\cline { 2 - 6 } & Cukup baik & 1 & 3.0 & 3.0 & 66.7 \\
\cline { 2 - 6 } & $\begin{array}{c}\text { Baik/setuju/ } \\
\text { memuaskan }\end{array}$ & 21 & 63.6 & 63.6 & 100.0 \\
\cline { 2 - 6 } & Sangat baik & 11 & 33.3 & 33.3 & \\
\cline { 2 - 6 } & Total & 33 & 100.0 & 100.0 & \multirow{2}{*}{} \\
\hline
\end{tabular}

\section{Kondisi kesehatan}

\begin{tabular}{|c|c|c|r|r|r|}
\hline \multirow{4}{*}{ Valid } & Frequency & Percent & \multicolumn{1}{|c|}{$\begin{array}{c}\text { Valid } \\
\text { percent }\end{array}$} & $\begin{array}{c}\text { Cumulative } \\
\text { percent }\end{array}$ \\
\cline { 2 - 6 } & Kurang baik & 10 & 30.3 & 30.3 & 30.3 \\
\cline { 2 - 6 } & Cukup baik & 17 & 51.5 & 51.5 & 81.8 \\
\hline
\end{tabular}

Manajerial, Vol. 2 No. 2 Januari 2017, Hal - 28

http://ejournal.upi.edu/index.php/manajerial/ 


\begin{tabular}{|r|c|r|r|r|r|}
\hline & $\begin{array}{c}\text { Baik/setuju/ } \\
\text { memuaskan }\end{array}$ & 5 & 15.2 & 15.2 & 97.0 \\
\cline { 2 - 5 } & Sangat baik & 1 & 3.0 & 3.0 & 100.0 \\
\cline { 2 - 5 } & Total & 33 & 100.0 & 100.0 & \\
\hline
\end{tabular}

\section{Kondisi Prasarana Lingkungan}

\begin{tabular}{|c|c|r|r|r|r|}
\hline \multirow{7}{*}{ Valid } & Frequency & Percent & \multicolumn{1}{|c|}{$\begin{array}{c}\text { Valid } \\
\text { percent }\end{array}$} & $\begin{array}{c}\text { Cumulative } \\
\text { percent }\end{array}$ \\
\cline { 2 - 6 } & Kurang baik & & & & 21.2 \\
\cline { 2 - 6 } & Cukup baik & 7 & 21.2 & 21.2 & 66.7 \\
\cline { 2 - 6 } & $\begin{array}{c}\text { Baik/setuju/ } \\
\text { memuaskan }\end{array}$ & 15 & 45.5 & 45.5 & 100.0 \\
\cline { 2 - 6 } & Sangat baik & 11 & 33.3 & 33.3 & \\
\cline { 2 - 6 } & Total & 33 & 100.0 & 100.0 & \\
\hline
\end{tabular}

\section{Kondisi tempat tinggal}

\begin{tabular}{|c|c|r|r|r|r|}
\hline \multirow{7}{*}{ Valid } & Frequency & Percent & \multicolumn{1}{|c|}{$\begin{array}{c}\text { Valid } \\
\text { percent }\end{array}$} & $\begin{array}{c}\text { Cumulative } \\
\text { percent }\end{array}$ \\
\cline { 2 - 6 } & Kurang baik & 1 & 3.0 & 3.0 & 3.0 \\
\cline { 2 - 6 } & Cukup baik & 15 & 45.5 & 45.5 & 48.5 \\
\cline { 2 - 6 } & $\begin{array}{c}\text { Baik/setuju/ } \\
\text { memuaskan }\end{array}$ & 13 & 39.4 & 39.4 & 87.9 \\
\cline { 2 - 6 } & Sangat baik & 4 & 12.1 & 12.1 & 100.0 \\
\cline { 2 - 6 } & Total & 33 & 100.0 & 100.0 & \\
\hline
\end{tabular}

\section{Akses usaha}

\begin{tabular}{|c|c|r|r|r|r|}
\hline \multirow{7}{*}{ Valid } & \multicolumn{1}{|c|}{ Frequency } & Percent & \multicolumn{1}{|c|}{$\begin{array}{c}\text { Valid } \\
\text { percent }\end{array}$} & \multicolumn{2}{c|}{$\begin{array}{c}\text { Cumulative } \\
\text { percent }\end{array}$} \\
\cline { 2 - 6 } & Kurang baik & 2 & 6.1 & 6.1 & 6.1 \\
\cline { 2 - 6 } & Cukup baik & 13 & 39.4 & 39.4 & 45.5 \\
\cline { 2 - 6 } & $\begin{array}{c}\text { Baik/setuju/ } \\
\text { memuaskan }\end{array}$ & 14 & 42.4 & 42.4 & 87.9 \\
\cline { 2 - 6 } & Sangat baik & 4 & 12.1 & 12.1 & 100.0 \\
\cline { 2 - 6 } & Total & 33 & 100.0 & 100.0 & \\
\hline
\end{tabular}

Prasarana lingkungan

\begin{tabular}{|c|c|r|r|r|r|}
\hline \multirow{7}{*}{ Valid } & \multicolumn{1}{|c|}{ Frequency } & \multicolumn{1}{c|}{ Percent } & \multicolumn{1}{c|}{$\begin{array}{c}\text { Valid } \\
\text { percent }\end{array}$} & $\begin{array}{c}\text { Cumulative } \\
\text { percent }\end{array}$ \\
\cline { 2 - 6 } & Kurang baik & 3 & 9.1 & 9.1 & 9.1 \\
\cline { 2 - 6 } & Cukup baik & 6 & 18.2 & 18.2 & 27.3 \\
\cline { 2 - 6 } & $\begin{array}{c}\text { Baik/setuju/ } \\
\text { memuaskan }\end{array}$ & 10 & 30.3 & 30.3 & 57.6 \\
\hline
\end{tabular}

Manajerial, Vol. 2 No. 2 Januari 2017, Hal - 29

http://ejournal.upi.edu/index.php/manajerial/ 


\begin{tabular}{|r|c|r|r|r|r|}
\hline & Sangat baik & 14 & 42.4 & 42.4 & 100.0 \\
\cline { 2 - 6 } & Total & 33 & 100.0 & 100.0 & \\
\hline
\end{tabular}

Kondisi budaya

\begin{tabular}{|c|c|r|r|r|r|}
\hline \multirow{7}{*}{ Valid } & \multicolumn{1}{|c|}{ Frequency } & \multicolumn{1}{c|}{ Percent } & \multicolumn{1}{c|}{$\begin{array}{c}\text { Valid } \\
\text { percent }\end{array}$} & \multicolumn{2}{c|}{$\begin{array}{c}\text { Cumulative } \\
\text { percent }\end{array}$} \\
\cline { 2 - 6 } & Kurang baik & 2 & 6.1 & 6.1 & 6.1 \\
\cline { 2 - 6 } & Cukup baik & 10 & 30.3 & 30.3 & 36.4 \\
\cline { 2 - 6 } & $\begin{array}{l}\text { Baik/setuju/ } \\
\text { memuaskan }\end{array}$ & 18 & 54.5 & 54.5 & 90.9 \\
\cline { 2 - 6 } & Sangat baik & 3 & 9.1 & 9.1 & 100.0 \\
\cline { 2 - 6 } & Total & 33 & 100.0 & 100.0 & \\
\hline
\end{tabular}

\section{Pengorganisasian}

\begin{tabular}{|c|c|r|r|r|r|}
\hline \multirow{7}{*}{ Valid } & \multicolumn{1}{|c|}{ Frequency } & Percent & \multicolumn{1}{c|}{$\begin{array}{c}\text { Valid } \\
\text { percent }\end{array}$} & $\begin{array}{c}\text { Cumulative } \\
\text { percent }\end{array}$ \\
\cline { 2 - 6 } & Kurang baik & & & & 12.1 \\
\cline { 2 - 6 } & Cukup baik & 4 & 12.1 & 12.1 & 75.8 \\
\cline { 2 - 6 } & $\begin{array}{c}\text { Baik/setuju/ } \\
\text { memuaskan }\end{array}$ & 21 & 63.6 & 63.6 & 100.0 \\
\cline { 2 - 6 } & Sangat baik & 8 & 24.2 & 24.2 & \\
\cline { 2 - 6 } & Total & 33 & 100.0 & 100.0 & \\
\hline
\end{tabular}

Dengan melakukan perhitungan jumlah total tabulasi pada nilai questioner sejumlah 1244 setelah di bandingkan dengan jumlah responden sebanyak 33 orang diketahui kesejahteraan masyarakat rata-rata skala likert sebesar 37,6 yang menunjukan nilai cukup Baik.

\section{Hasil Korelasi antara Variabel CSR dengan Kesejahteraan Masyarakat}

Setelah dihitung program SPSS diketahui nilai korelasi antara program CSR dengan kesejahteraan masyarakat Karawang adalah sebagai berikut :

\section{Descriptive Statistics}

\begin{tabular}{|c|r|r|r|}
\hline & Mean & Std. Deviation & N \\
\hline $\begin{array}{c}\text { Peran CSR } \\
\text { Perbankan }\end{array}$ & 39.9394 & 3.84008 & 33 \\
$\begin{array}{c}\text { Kesejahteraan } \\
\text { Masyarakat } \\
\text { Karawang }\end{array}$ & 37.6970 & 4.04262 & 33 \\
\hline
\end{tabular}

Manajerial, Vol. 2 No. 2 Januari 2017, Hal - 30 


\section{Correlations}

\begin{tabular}{|c|c|c|c|}
\hline & & Peran CSR Perbankan & $\begin{array}{l}\text { Kesejahteraan Masyarakat } \\
\text { Karawang }\end{array}$ \\
\hline & $\begin{array}{l}\text { Pearson } \\
\text { Correlation }\end{array}$ & 1 & $.492^{* *}$ \\
\hline & & & .004 \\
\hline Peran CSR & $\begin{array}{l}\text { Sum of } \\
\text { Sauraes and }\end{array}$ & & \\
\hline Perbankan & $\begin{array}{l}\text { Cquares and } \\
\text { Cross- } \\
\text { products }\end{array}$ & 471.879 & 244.394 \\
\hline & Covariance & 14.746 & 7.637 \\
\hline & $\mathrm{N}$ & 33 & 33 \\
\hline & $\begin{array}{l}\text { Pearson } \\
\text { Correlation }\end{array}$ & $.492^{* * *}$ & 1 \\
\hline & Sig. (2-tailed) & .004 & \\
\hline Kesejahteraan & Sum of & & \\
\hline $\begin{array}{l}\text { Masyarakat } \\
\text { Karawang }\end{array}$ & $\begin{array}{c}\text { Squares and } \\
\text { Cross- } \\
\text { products }\end{array}$ & 244.394 & 522.970 \\
\hline & Covariance & 7.637 & 16.343 \\
\hline & $\mathrm{N}$ & 33 & 33 \\
\hline
\end{tabular}

Nilai korelasi atau hubungan antara program CSR dengan kesejahteraan masyarakat sebesar 0,492 , selanjutnya dilakukan perhitungan koefisien determinasi dapat diketahui kontribusi Program CSR dengan Kesejahteraan Masyarakat sebesar 24 persen.

\section{Uji Hipotesis}

Menghitung uji korelasi dengan membandingkan $t$ hitung dengan $t$ tabel

$$
\begin{aligned}
\text { thitung } & =\frac{\Gamma x y \sqrt{n-2}}{\sqrt{1-(\Gamma x y)^{2}}} \\
& =\frac{0,49 \sqrt{33-2}}{\sqrt{1-(0,49)^{2}}} \\
& =\frac{0,49 \sqrt{31}}{\sqrt{1-0,24}} \\
& =\frac{0,49(5,56)}{\sqrt{0.76}} \\
& =\frac{2.72}{0.76} \\
& =3.57
\end{aligned}
$$

Diketahui $\alpha$ (taraf nyata) $=5 \%=0,05$

$$
\begin{aligned}
t \text { tabel } & =t(33-2 ; \alpha) \\
& =t(31 ; 0,05)
\end{aligned}
$$




$$
=2,042
$$

Kesimpulan :

Karena $t$ hitung > t tabel atau 3,57> 2,042 maka koefisien korelasi signifikan / bermakna, dengan kata lain artinya terdapat hubungan atau korelasi sangat tinggi antara pengaruh CSR Perbankan dengan kesejahteraan masyararakat di Kabupaten Karawang.

\section{CONCLUSION}

\section{A. KESIMPULAN}

Kesimpulan hasil penelitian tentang program CSRPerbankan dengan kesejahteraan masyarakat dapat disimpulkan bahwa :

1. Hasil analisa frekuensi questioner yang disebar kepada 33 orang pada table deskripsi frequensi untuk kegiatan CSR dengan nilairata-rata 39,8 yang artinya berdasarkan interval skala likert menunjukan hasil yang baik. Sedangkan untuk mengetahui kesejahteraan masyarakat menunjukan angka rata-rata 37,6 yang artinya cukup baik.

2. Hasil perhitungan korelasi tentang CSRPerbankan dengan kesejahteraan masyarakat menunjukan hasil korelasi sebesar 0,49 dari hasil perhitungan menunjukan bahwa terhadi hubungan korelasi yang positif antara kedua variable dengan hubungan yang sedang.

3. Hasil koefisien determinasi menunjukan kontribusi CSR Perbankan terhadap peningkatan kesejahteraan masyarakat sebesar 24 persen artinya masih banyak factor lainya yang dapat mempengaruhi kesejahteraan masyarakat.

\section{DAFTAR PUSTAKA}

Duwi Priyanto, (2009), Belajar Mengolah data dengan SPSS 17. Penerbit Andi Yogyakarta

Hermansyah, (2008). Hukum Perbankan Nasional Indonesia, Edisi Revisi, Kencana Jakarta :

Iskandar Putong, (2003). Pengantar Ekonomi Mikro dan Makro, Penerbit PT. Ghalia Indonesia, Jakarta

\section{Rancangan Rencana Pembangunan Jangka Menengah Daerah (RPJMD) Kabupaten}

KarawangTahun 2011-2015, BAPPEDA Karawang

Suharsimi Arikunto(2006), MetodePenelitian, BinaAksara, Jakarta

Sugiyono, Prof. Dr. (2011) Metode Penelitian Pendekatan Kualitatif Kuantitatif dan $R$ \& $D$, Penerbit Alfhabeta Bandung

SadonoSukirno, (2007). Ekonomi Pembangunan Edisi Kedua. Kencana Prenada Media Group, Jakarta

UUPT ketentuan mengenai CSR. Pengertian CSR diaturdi dalamPasal 1 butir (3)

\section{CSRTwitter $\underline{E}$ _dan Facebook $f$}

Manajerial, Vol. 2 No. 2 Januari 2017, Hal - 32

http://ejournal.upi.edu/index.php/manajerial/

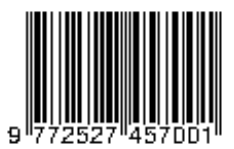


ISSN : $1412-6613$

E-ISSN : 2527 - 4570

Manajerial, Vol. 2 No. 2 Januari 2017, Hal - 33

http://ejournal.upi.edu/index.php/manajerial/ 